\title{
Penambahan Ekstrak Daun Mangrove Rhizophora apiculata pada Pakan Udang Vaname (Litopenaeus vannamei) untuk Pencegahan Vibriosis
}

\section{The Addition of Mangrove Leaf Extract Rhizophora apiculata in White Shrimp (Litopenaeus vannamei) for Vibriosis Prevention}

\author{
Nur Fadillah ${ }^{1 *}$, Saptono Waspodo ${ }^{1}$, Fariq Azhar ${ }^{1}$ \\ Laboratorium Budidaya Perairan \\ Program Studi Budidaya Perairan, Universitas Mataram \\ Jl. Pendidikan No, 37 Mataram, NTB \\ "Email: nnurfadillah6@gmail.com
}

\begin{abstract}
Abstrak
Udang vaname merupakan salah satu komoditas air payau yang menjadi solusi untuk menggantikan udang windu (Penaeus monodon) yang mengalami penurunan kualitas. Salah satu kendala dalam budidaya udang vaname yaitu serangan vibriosis, disebabkan oleh genus vibrio species $V$. parahaemolyticus. Penelitian ini bertujuan untuk mengetahui pengaruh penambahan ekstrak daun mangrove Rhizophora apiculata dengan dosis berbeda pada pakan udang vaname untuk pencegahan vibriosis. Udang diberi ekstrak daun mangrove selama 40 hari dan diuji tantang selama 7 hari pada kontainer ukuran $40 \mathrm{~cm}$ x $30 \mathrm{~cm}$ x $28 \mathrm{~cm}, 20$ ekor/wadah volume 20 liter. Penelitian dilakukan dalam 5 perlakuan, kontrol+ (Pakan tanpa ekstrak+Infeksi), kontrol- (pakan tanpa ekstrak), P3 (0,5\%+Infeksi), P4 (1\% ekstrak+Infeksi), P5 (2\% ekstrak +Infeksi), dosis bakteri yang diinjeksi $0,1 \mathrm{ml} /$ ekor kepadatan $10^{6} \mathrm{cfu} / \mathrm{ml}$. Hasil penelitian menunjukkan, pemberian ekstrak daun mangrove dengan dosis 2\% mampu mempertahankan SR sebesar 76,67\%, meningkatkan THC udang sebesar $7,55 \times 10^{6} \mathrm{sel} / \mathrm{ml}$ dan DHC (sel hialin 84,3\% dan granular $15,3 \%$ ) yang berperan dalam sistem imun udang. Jumlah bakteri dan jumlah vibrio di usus yaitu, $64.7 \times 10^{8} \mathrm{cfu} / \mathrm{ml}$ dan $16 \times 10^{8} \mathrm{cfu} / \mathrm{ml}$. Berdasarkan hasil penelitian, penggunaan ekstrak daun mangrove ini dapat digunakan pada budidaya udang vaname sebagai imunostimulan karena dapat meningkatkan kelangsungan hidup, THC, DHC dan mengurangi bakteri pada usus udang vaname.
\end{abstract}

Keyword : Ekstrak, Daun mangrove, Vibriosis, Udang Vaname, Pakan.

\begin{abstract}
White shrimp is a brackish water commodity which is a solution to approve tiger shrimp (Penaeus monodon) which improves quality. One of the challenges in the cultivation of white shrimp is the attack of vibriosis, caused by the vibrio genus species $V$. parahaemolyticus. Rhizophora apiculata mangrove leaf extract with different dosages in white shrimp feed to increase vibriosis. Shrimp were given mangrove leaf extract for 40 days and were challenged for 7 days in a $40 \mathrm{~cm} \times 30 \mathrm{~cm} \times 28 \mathrm{~cm}$ container, 20 heads $/ 20$ liter volume container. The study was conducted in 5 training, control + (Feed without extract + Infection), control- (feed without extract), P3 (0,5\% + Infection), P4 (1\% extract + Infection), P5 (2\% extract + Infection ), the injected bacterial dose is $0.1 \mathrm{ml} / \mathrm{heads}$ density of $10^{6} \mathrm{cfu} / \mathrm{ml}$. The results showed that administration of mangrove leaf extract at a dose of $2 \%$ was able to maintain SR of $76,67 \%$, increasing shrimp THC by $7,55 \times 106$ cells $/ \mathrm{ml}$ and DHC (hyaline cells $84,3 \%$ and granular 15,3\%) which plan in the shrimp immune system. The number of bacteria and the amount of vibrio in the intestine is, $64,7 \times 108 \mathrm{cfu} / \mathrm{ml}$ and $16 \times 108 \mathrm{cfu} / \mathrm{ml}$. Based on the results of the study, the use of mangrove leaf extract can be used in the cultivation of white shrimp as an immunostimulant because it can increase survival, THC, DHC and reduce bacteria in the intestines of white shrimp.
\end{abstract}

Keyword : Extracts, Mangrove leaves, Vibriosis, White Shrimp, Feed. 


\section{PENDAHULUAN}

Salah satu komoditas air payau yang sering dibudidayakan adalah Udang vaname. Udang ini dikenal menjadi salah satu solusi untuk menggantikan udang windu (Penaeus monodon) yang mengalami penurunan kualitas berdasarkan SK Menteri Kelautan dan Perikanan RI. NO.4/2001 tentang pelepasan varietas udang vaname sebagai varietas unggul. Udang vaname termasuk komoditi yang mudah dibudidayakan karena memiliki beberapa keunggulan dibandingkan udang windu, sehingga para petani tambak tertarik untuk membudidayakan udang vaname (Purnamasari et al., 2017). Namun demikian, kendala yang dihadapi selama proses pembesaran udang vaname salah satunya adalah serangan penyakit. Penyakit merupakan masalah serius dalam budidaya udang vaname (Sari et al., 2015).

Salah satu penyakit yang menyerang udang vaname adalah vibriosis. Keberadaan bakteri Vibrio sp. ini merupakan flora normal bagi udang vaname yang memiliki batas maksimum (Chandrakala dan Menaka, 2017).

Serangan bakteri Vibrio sp. bersifat pathogen sehingga menyebar dengan cepat dan mampu menyebabkan kematian hingga $85 \%$ (Sarjito et al., 2015). Selama ini pemberian antibiotik sintetik secara terus menerus dengan dosis yang tidak tepat memberikan dampak resistensi pada bakteri, mencemari lingkungan dan membahayakan konsumen (Putri et al., 2015).

Daun mangrove Rhizopora apiculata merupakan salah satu bahan obat yang dapat menghambat perkembangan bakteri karena terdapat senyawa bioaktif seperti alkaloid, tanin, saponin, fenol, flavonoid dan terpenoid yang terbukti dapat menekan petumbuhan bakteri karena bersifat sebagai antibakteri. Spesies mangrove memiliki sifat antimikroba khususnya terhadap bakteri Vibrio sp (Susanti et al., 2016). Ekstrak daun lebih efektif dibandingkan buah dan kulit batangnya (Suciati et al., 2012). Akan tetapi, pada ekstrak daun mangrove ini terdapat senyawa fenol yang dapat mengobati luka akibat infeksi bakteri dengan cara 
merusak dan menembus dinding sel (Putri et al., 2015).

Pencegahan vibriosis melalui senyawa yang terkandung di dalam ekstrak daun mangrove Rhizopora sp. bahan aktif saponin, flavonoid, tanin, fenol dan alkoloid dapat menjaga daya tahan tubuh kultivan dari serangan penyakit sebagai antibakteri. Selain itu juga, kandungan flavonoid dapat mencegah oksidasi dan menghambat penyebaran luka secara cepat (Putri et al., 2015).

Penelitian ini mengkaji pengaruh ekstrak daun mangrove dengan dosis berbeda yang ditambahkan pada pakan udang vaname. Dosis yang tepat juga menjadi salah satu faktor penting yang dapat menjaga daya tahan tubuh udang akibat serangan antibakteri (Susanti, 2016). Oleh karena itu, dalam pencegahan vibriosis akibat serangan bakteri $V$. parahaemolyticus sangat penting dilakukan mengingat ganasnya serangan bakteri ini pada sebagian besar udang vaname yang dibudidayakan. Selain itu, pemberian bahan alami dengan dosis yang tepat akan berpengaruh pada kesehatan udang melalui tindakan pencegahan serangan vibriosis yang terjadi pada udang vaname. Tujuan penelitian ini adalah untuk mengetahui pengaruh penambahan ekstrak daun mangrove Rhizophora apiculata dengan dosis berbeda pada pakan udang vaname untuk pencegahan vibriosis.

\section{METODE PENELITIAN}

\section{Lokasi dan Waktu Penelitian}

Penelitian ini dilaksanakan di Laboratorium Budidaya Perairan, Universitas Mataram selama 56 hari yaitu dari 23 Mei 2017 sampai 17 Juli 2017.

\section{Persiapan Wadah dan Ikan Uji}

Udang vaname yang digunakan pada penelitian ini adalah benur PL20 dengan berat 0,02 g/ekor dan dipelihara dengan padat tebar 20 ekor/wadah. Wadah yang digunakan yaitu kontainer plastik dengan ukuran $40 \mathrm{~cm} \times 30 \mathrm{~cm} \times 28 \mathrm{~cm}$ dengan volume air laut $20 \mathrm{~L}$, dilengkapi shelter, perangkat aerasi dengan sistem pergantian air (penyiponan) secara berkala setiap satu kali sehari.

\section{Pembuatan Ekstrak}


Pembuatan ekstrak daun mangrove Rhizopohora apiculata diawali dengan pengambilan daun mangrove di Desa Cemara, Lombok Barat. Tahap selanjutnya dilakukan pencucian dan dibersihkan daun mangrove dengan air tawar lalu ditiriskan dan dikeringkan sampai layu. Kemudian, daun yang sudah dijemur tadi dioven dengan suhu $70^{\circ}$ $\mathrm{C}$ selama 4 jam sehingga daun kering dan bisa dipatahkan. Setelah dikeringkan dengan oven daun mangrove dibuat menjadi tepung dengan belender dan diayak sampai diperoleh bubuk halus. Tahap selanjutnya, tepung daun mangrove direndam dengan etanol $90 \%$ (Suciati, 2012). Perbandingan pelarut dengan tepung daun mangrove yaitu, 1:5 (Septiani, 2018). Kemudian bahan disaring agar diperoleh larutan ekstrak tanpa ampas diulangi sebanyak 3 kali. Hasil dari saringan pertama sampai ketiga dicampurkan dan dipekatkan dengan rotary vacum evaporator pada suhu $50^{\circ} \mathrm{C}$ sampai didapatkan ekstrak pekat dengan metode evaporasi (Putri, 2015).

\section{Persiapan Pakan Uji}

Pakan yang digunakan dalam penelitian ini adalah pakan crumble
681 dengan kadar protein $30 \%$. Pakan ditambahkan ekstrak menggunakan mikropipet (20 - 200 $\mu$ dengan dosis berbeda sesuai perlakuan yaitu $0,5 \%, 1 \%$ dan $2 \%$ dari total pakan yang diberikan selama 10 hari, lalu dicampur hingga merata dengan sendok spatula dan dikering anginkan sedangkan kontrol + dan - tidak diberikan ekstrak daun mangrove (Jannah, 2018).

\section{Prosedur Kerja}

Perlakuan yang diberikan yakni dengan penambahan ekstrak daun mangrove Rhizophora apiculata berdasarkan jumlah pakan dengan berbagai kombinasi yakni P3 $($ Pakan + ekstrak 0,5\% + Infeksi bakteri), untuk P4 (Pakan + ekstrak $1 \%+$ Infeksi bakteri), dan untuk P5 $($ Pakan + ekstrak 2\% + Infeksi bakteri), kontol positif (P1) (Pakan tanpa ekstrak + infeksi bakteri) dan kontrol negatif (P2) (Pakan tanpa ekstrak + infeksi $\mathrm{NaCl}$ 0,9\%). Pemeliharaan udang vaname dengan pakan yang ditambahkan ekstrak daun mangrove dilakukan selama 40 hari, setelah itu dilakukan uji tantang dengan bakteri selama 7 hari (Azhar, 2018). Jenis bakteri yang diinfeksikan ke udang yaitu, $V$. 
parahaemolyticus

secara

intramuscular (Rahmanto et al., 2014). Dosis bakteri yang diifeksikan sebanyak 0,1 mL/ekor dengan kepadatan bakteri $10^{6} \mathrm{cfu} / \mathrm{ml}$ (Apriliani et al., 2016).

\section{Analisis Data}

Data parameter kelangsungan hidup (SR), total haemocyte count (THC), differential haemocyte count (DHC), total bakteri dan total vibrio dianalisa secara statistik menggunakan one way-analisis of variance dengan SPSS (Versi 16.0) pada taraf kepercayaan $95 \%$ $(\mathrm{P}<0,05)$. Jika hasil berbeda nyata maka dilakukan uji lanjut dengan Tukey HSD.

\section{HASIL DAN PEMBAHASAN}

\section{Hasil}

\section{Kelangsungan Hidup}

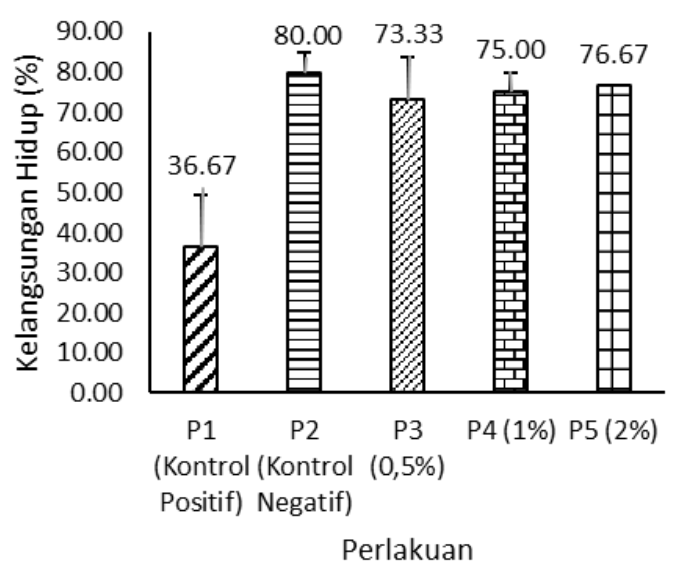

Gambar 1. Kelangsungan hidup udang uji (Litopenaeus vannamei) pasca uji tantang dengan $V$. parahaemolyticus
Secara matematis nilai kelangsungan hidup udang tertinggi setelah dilakukan uji tantang yaitu pada P2 (Pakan tanpa ekstrak + infeksi $\mathrm{NaCl}$ 0,9\%) sebesar 80\%, diikuti dengan P5 (Pakan + ekstrak $2 \%+$ Infeksi bakteri) sebesar $76,67 \%$, kemudian P4 (Pakan + ekstrak 1\% + Infeksi bakteri) sebesar 75\%, untuk P3 (Pakan + ekstrak $0,5 \%+$ Infeksi bakteri) yaitu $73,33 \%$ dan paling rendah yaitu P1 (Pakan tanpa ekstrak + infeksi bakteri) sebesar 36,67\% (Gambar 1). Namun demikian secara statistik dengan uji One-Way Annova dan uji lanjut Tukey, pemberian ekstrak daun mangrove memberikan pengaruh signifikan $(\mathrm{P}>0,05)$ antara $\mathrm{P} 1$ (kontrol positif) dengan perlakuan lainnya. Kontrol positif berbeda nyata dengan semua perlakuan.

\section{Total Haemocyte Count (THC)}

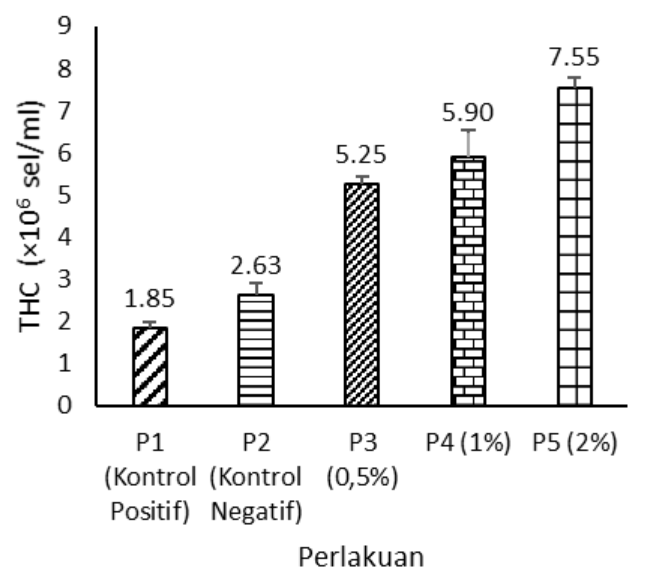


Gambar 2. Total Haemocyte Count (THC) udang uji (Litopenaeus vannamei) pasca uji tantang dengan $V$. parahaemolyticus

Jumlah hemosit (THC) secara matematis yang tertinggi yaitu pada P5 (Pakan + ekstrak 2\% + Infeksi bakteri) sebesar $7,55 \times 10^{6} \mathrm{sel} / \mathrm{ml}$ diikuti P4 (Pakan + ekstrak 1\% + Infeksi bakteri) sebesar $5,90 \times 10^{6}$ sel/ml, setelah itu P3 (Pakan + ekstrak $0,5 \%$ + Infeksi bakteri) yaitu, $5,25 \times 10^{6} \mathrm{sel} / \mathrm{ml}$. Sementara P2 (Pakan tanpa ekstrak + infeksi $\mathrm{NaCl}$ $0,9 \%$ ) sebesar $2,63 \times 10^{6} \mathrm{sel} / \mathrm{ml}$ dan paling rendah yaitu (Pakan tanpa ekstrak + infeksi bakteri) sebesar $1,85 \times 10^{6} \mathrm{sel} / \mathrm{ml} \quad($ Gambar 2). Namun demikian secara statistik dengan uji One-Way Annova dan uji lanjut Tukey, diperoleh pengaruh signifikan $(\mathrm{P}>0,05)$ antara $\mathrm{P} 1$ (kontrol positif) dan P2 (kontrol negatif) dengan P3, P4 dan P5.

\section{Differensial Haemocit Count (DHC)}

(A)

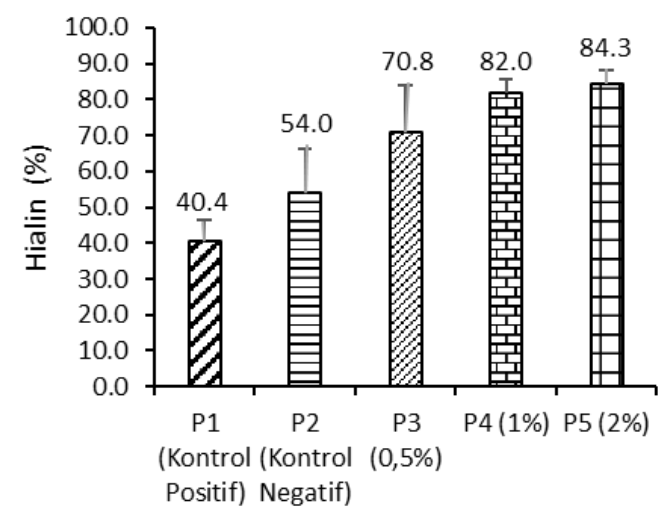

(B)

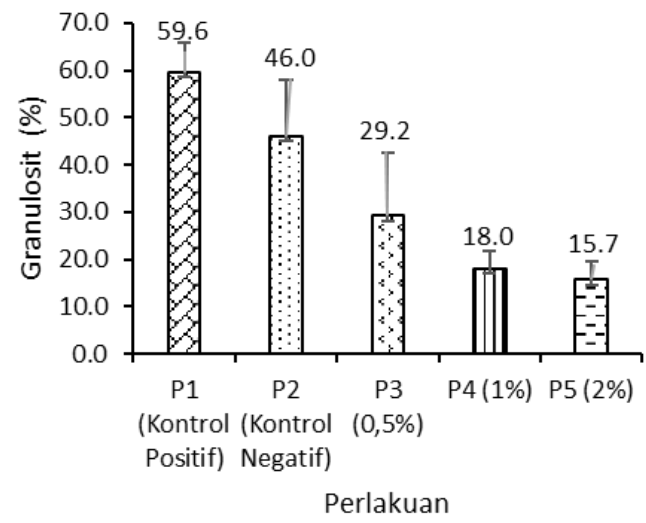

Gambar 3. Differential Haemocyte Count (THC) udang uji (Litopenaeus vannamei) pasca uji tantang dengan $V$. parahaemolyticus; A (hialin); B (granulosit).

Berdasarkan hasil pengamatan DHC jumlah hialin tertinggi terdapat pada P5 (Pakan + ekstrak 2\% + Infeksi bakteri) sebesar 84,3\% dan yang terendah yaitu P1 (Pakan tanpa ekstrak + infeksi bakteri) sebesar 40,4\%. Sementara itu, jumlah granulosit tertinggi pada P1 (Pakan tanpa ekstrak + infeksi bakteri) yaitu $59,6 \%$ dan yang terendah terdapat pada P5 (Pakan + ekstrak 2\% + Infeksi bakteri) sebesar $15,7 \%$ (Gambar 3). Apabila dilihat dari hasil uji One-Way Annova menunjukkan pengaruh signifikan $(\mathrm{P}<0,05)$ antara kontrol positif dan P5 dengan dosis ekstrak 2\% pada jumlah hialin serta begitupun pada jumlah granulosit memiliki pola 
yang sama. 4. Total bakteri dan Total

Vibrio. perlakuan tersebut tidak diinjeksi dengan bakteri $V$. parahaemolyticus.

Tabel 1. Jumlah total bakteri dan total vibrio (cfu/ml)

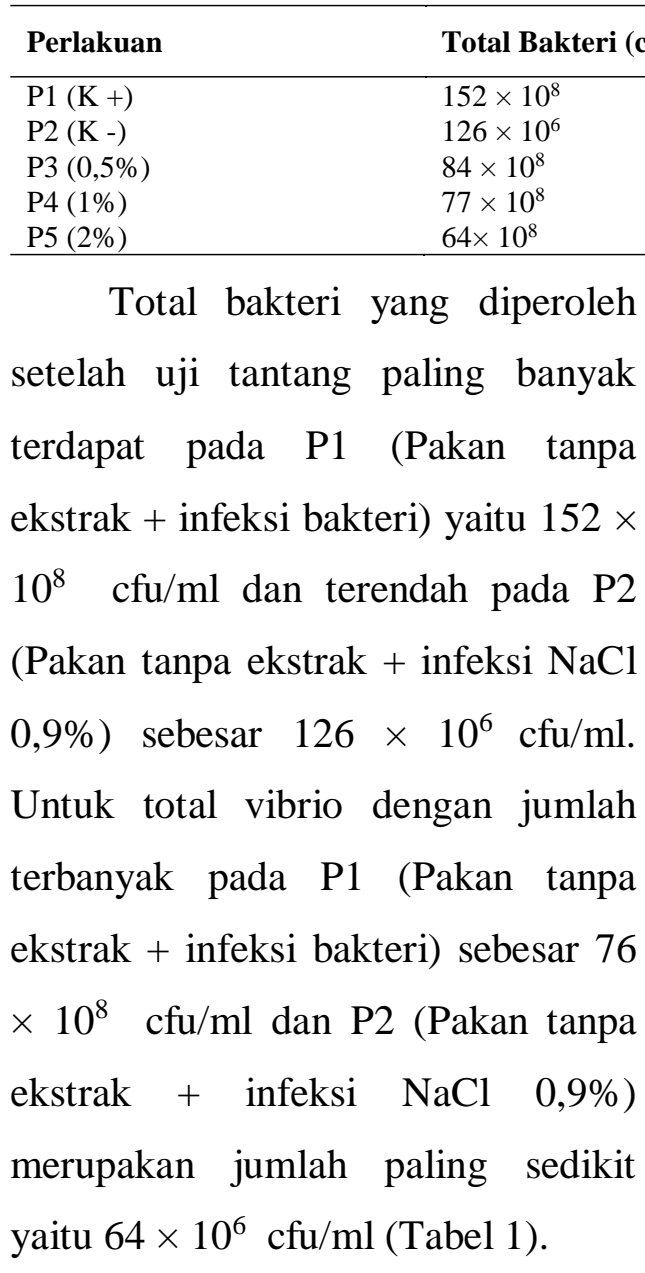

\section{Pembahasan}

$\begin{array}{rlr}\text { Ekstrak } & \text { daun mangrove } \\ \text { Rhizophora } & \text { apiculta } & \text { dapat }\end{array}$
membantu pertahanan udang vaname dari serangan bakteri yang dilihat dari mortalitas yang rendah pada perlakuan yang diberi ekstrak dibandingkan kontrol. Namun demikian, penyebab tingginya tingkat kelangsungan hidup pada kontrol negatif ini dikarenakan pada
Total Vibrio (cfu/ml)

$76 \times 10^{8}$

$64 \times 10^{6}$

$39 \times 10^{8}$

$20 \times 10^{8}$ $16 \times 10^{8}$

Udang yang diinfeksi $V$. parahaemolyticus dengan konsentrasi $10^{4} \mathrm{cfu} / \mathrm{ml}$ mampu membunuh 50\% dari populasi udang selama satu minggu (Rahmanto et $a l ., 2014)$. Vibriosis dapat menyebar dengan cepat hingga mampu menyebabkan mortalitas hingga $85 \%$ (Sarjito et al., 2015). Peningkatan respon imun udang mampu meningkatkan nilai kelangsungan hidup udang, karena peningkatan resistensi udang terhadap patogen (Azhar, 2018). Nilai kelangsungan hidup tertinggi pada P2 (kontrol negatif) sebesar $80 \%$ akan tetapi, untuk yang diinfeksi bakteri P5 merupakan nilai kelangsungan hidup tertinggi sebesar $76,67 \%$. Peningkatan kelangsungan hidup yang semakin tinggi seiring dengan pemakaian dosis yang semakin tinggi diduga berkaitan dengan kandungan dari ekstrak daun bakau (Putri et al., 2015). Tingkat kelangsungan hidup 
pada kontrol negatif merupakan hasil yang paling tinggi dikarenakan pada perlakuan kontrol negatif tidak dilakukan infeksi dengan $V$. harveyi serta tanpa penambahan sinbiotik pada pakan (Oktaviana, 2014).

Pemberian ekstrak daun mangrove Rhizophora apiculata pada penelitian ini berpengaruh pada peningkatan jumlah hemosit sehingga mengurangi dampak infeksi $V$. parahemolyticus dengan kepadatan $10^{6} \mathrm{cfu} / \mathrm{ml}$. Dari hasil pengamatan jumlah hemosit tertinggi pada P5 yaitu sebesar $7,55 \times 10^{6}$ sel/ml dibandingkan P1 (kontrol positif) dengan jumlah paling sedikit yaitu, $1,85 \times 10^{6} \mathrm{sel} / \mathrm{ml}$. Berdasarkan penelitian Paramitha et al., (2017), melalui pemberian ekstrak daun mangrove Rhizophora stylosa mampu melindungi post larva udang windu dari serangan $V$. harveyi yang dilihat dari prevalensi dan kelangsungan hidup post larva udang windu, kondisi tersebut dapat merangsang pembentukan sel kekebalan tubuh pada udang. Peningkatan jumlah hemosit mengindikasikan respon imun yang meningkat pada udang vaname terhadap patogen yang ditandai dengan penurunan jumlah parasit maupun infeksi (Rohmin et al., 2017). Peran hemosit yaitu dalam mekanisme pertahanan tubuh krustase, karena dapat meminimalisir partikel asing di dalam tubuh udang (Azhar, 2018).

Pada penelitian ini jumlah sel hialin tertinggi terdapat pada P5 yaitu, $84,3 \%$ dari total hemosit dengan jumlah granulosit paling sedikit sebesar $15,7 \%$. Jumlah sel hemosit yang meningkat disebabkan karena imunostimulan terserap dalam tubuh udang vaname serta memacu hemosit untuk melakukan degranulasi serta peningkatan aktivitas fagosit (Darwantin et al., 2016). Peningkatan jumlah sel hialin berhubungan dengan aktivitas fagositosis sedangkan sel granular berperan dalam produksi melanin pada proses sitotoksik (Hauton, 2012). jumlah hemosit merupakan indikator terjadi infeksi patogen di tubuh inang sehingga terjadi inflamasi sebagai pertahanan non spesifik, karena terdapat beberapa faktor yang mempengauhi seperti parasit, bakteri, jamur dan virus (Rohmin et al., 2017). 
Jumlah bakteri pada usus udang pasca infeksi berbeda signifikan dengan jumlah bakteri tanpa infeksi dengan $V$. parahemolyticus. Hal tersebut juga terjadi pada jumlah vibrio total, sehingga dapat diketahui bahwa pemberian ekstrak daun mangrove Rhizophora apiculata ini mampu mengurangi jumlah bakteri total maupun vibrio total (Tabel 1). Kontrol positif memiliki jumlah bakteri tertinggi dari semua perlakuan yaitu $152 \times 10^{8} \mathrm{cfu} / \mathrm{ml}$, sedangkan pada P5 dengan dosis ekstrak tertinggi memiliki jumlah bakteri paling sedikit yaitu $64,67 \times$ $10^{8} \mathrm{cfu} / \mathrm{ml}$ dan lebih tinggi dari pada kontrol negatif (tanpa ekstrak dan infeksi bakteri) yaitu, $126 \times 10^{6}$ cfu/ml. Pada ekstrak daun mangrove Rhizophora apiculata terdapat kandungan bahan aktif seperti, alkoloid, steroid, saponin, fenol, flavonoid, dan terpenoid yang berperan sebagai antibakteri dan antiseptik untuk menekan pertumbuhan bakteri. Sebagian besar tanaman ini mengandung senyawa yang beracun bagi bakteri patogen seperti fenol yang berperan dalam penghancuran dinding sel serta presipitasi (penguapan) dan denaturasi protein yang pada akhirnya dapat melisiskan sel bakteri (Poomphozil dan Kumarasamy, 2014).

Kontrol positif memiliki total koloni vibrio paling banyak dari semua perlakuan $76 \times 10^{8} \mathrm{cfu} / \mathrm{ml}$, sedangkan total vibrio paling sedikit terdapat pada P5 yaitu, $16 \times 10^{8}$ $\mathrm{cfu} / \mathrm{ml}$ lebih tinggi dari kontrol negatif yaitu $64 \times 10^{6} \mathrm{cfu} / \mathrm{ml}$. Pada pemberian ekstrak Rhizophora stylosa untuk udang windu sebelum dilakukannya uji tantang menyebabkan bakteri yang masuk menjadi lemah bahkan mati karena terdapat senyawa bioaktif seperti flavonoid, steroid, tanin serta fenol yang aktif sebagai bahan antimikroba (Paramitha et al., 2017). Banyaknya jumlah vibrio pada P3 sementara diberi ekstrak dengan dosis $0,5 \%$ diduga dosis yang diberikan terlalu sedikit untuk menekan jumlah vibrio pada usus udang vaname, dapat dilihat juga pada pemberian dosis probiotik $10^{6} \mathrm{cfu} / \mathrm{ml}$ pada penelitan lain diduga belum cukup menekan bakteriosin (protein yang disekresikan bakteri probiotik untuk menghambat pertumbuhan bakteri 
merugikan $V$. parahaemolyticus) sehingga keberadaan bakteri probiotik menurun akibat bakteri merugikan $V$. parahaemolyticus (Jannah et al., 2018).

\section{KESIMPULAN DAN SARAN}

\section{Kesimpulan}

Ekstrak daun mangrove Rhizophora apiculata dengan dosis $2 \%$ merupakan dosis yang terbaik dalam pencegahan vibriosis yang dilihat dari parameter uji pada penelitian ini, pada total bakteri dan total vibrio di usus paling rendah sebesar $64.7 \times 10^{8} \mathrm{cfu} / \mathrm{ml}$ dan $16 \times$ $10^{8} \mathrm{cfu} / \mathrm{ml}$, dengan kelangsungan hidup sebesar 76,67\%. Sedangkan, jumlah THC sebesar 7,55 $\times 10^{6}$ sel $/ \mathrm{ml}$, persentase hialin $84,3 \%$ serta granulosit sebesar $15,3 \%$.

\section{Saran}

$$
\text { Perlu dilakukan penelitian }
$$
lanjutan terkait cara kerja sistem imun udang melalui aktivitas PO (Phenol Oksidase).

\section{UCAPAN TERIMA KASIH}

Penulis mengucapkan terimakasih Kepada

Dosen

Pembimbing serta institusi perguruan tinggi dalam hal ini Universitas
Mataram sebagai tempat peneliti menimba ilmu dan pengetahuan..

\section{DAFTAR PUSTAKA}

Apriliani, M., Sarjito., Haditomo, A. H. C. 2016. Keanekaragaman Agensia Penyebab Vibriosis pada Udang Vaname (Litopenaeus vannamei) dan Sensitivitasnya terhadap Antibiotik. Jurnal of Aquaculture Management and Technology, 5 (1): 98-107.

Azhar, F. 2018. Aplikasi Bioflok yang dikombinasikan dengan Probiotik untuk Pencegahan Infeksi Vibrio parahaemolyticus pada Pemelihaaran Udang Vaname (Litopenaeus vannamei). Journal of Aquaculture Science, 3 (1): 128137.

Chandrakala, N dan Menaka. R. 2017. Vibriosis - Detection And Pathology. International Journal of Current Innovation Research, 3: 622-626.

Darwantin, K., Sidik, R dan Mahasari, G. 2016. Efisiensi penggunaan imunostimulan dalam pakan terhadap laju pertumbuhan, respon imun dan kelulushidupan udang vannamei (Litopenaeus vannamei). Jurnal Biosains Pascasarjana 18, (2).

Hauton, C. 2012. The scope of the crustacean immune system for disease control. Journal of Invertebrate Pathology 110, (2) :251-260.

Jannah, M., Junaidi, M., Setyowati, D.N dan Azhar, F. 2018. Pengaruh Pemberian Lactobacillus sp. dengan Dosis yang Berbeda Terhadap Sistem Imun Udang Vaname (Litopenaeus vannamei) yang Diinfeksi 
Bakteri

Vibrio

parahaemolyticus.

Jurnal

Kelautan 11, (2).

Oktaviana, A. 2014. Kajian pemberian sinbiotik dengan frekuensi berbeda unntuk pencegahan koinfeksi infectious myonecrosis virus dan Vibrio harveyi pada udang vaname (Litopenaeus vannamei). Tesis. Institut Pertanian Bogor.

Paramitha, E., Septiani, G., dan Pebrianto, C. G. 2017. Pemberian Ekstrak Daun Rhizophora Stylosa Untuk Melindungi Post Larva Udang Windu (Penaeus monodon) Terhadap Serangan Vibrio harveyi. TFS, 23 (1).

Poompozhil, S. dan Kumarasamy, D. 2014. Studies on Phytochemical Constituents of Some Selected Mangroves. $J$ of Academia and Industrial Research (JAIR), 10 (2): 2 .

Purnamasari. I., Purnama, D., dan Utami, M. A. F. 2017. Pertumbuhan Udang Vaname (Litopenaeus vanamei) di Tambak Intensif. Jurnal Enggano, 2 (1): 58-67.

Putri, A. M., Prayitno, S. B., Sarjito. 2015. Perendaman Berbagai Dosis Ekstrak Daun Bakau (Rhizophora apiculata) Untuk Pengobatan Kepiting Bakau (Scylla serrata) Yang Diinfeksi Bakteri Vibrio harveyi. Jornal of Aquaculture Management and Technology, 4 (4): 141-149.

Rahmanto, S. P., Sarjito \& Chilmawati, D. 2014. Karakterisasi Dan Uji Postulat Koch Bakteri Genus Vibrio Yang Berasal Dari Media Kultur Massal Mikroalga. Journal of Aquaculture Management and Technology, 3 (4): 230-237.
Rohmin, M. F. T., Mahasari, G dan Rantam, F. A. 2017. Response Analysis of Urban Vaname (Litopenaeus vannamei) Which ss Exposed to Crude Protein Zoothamniumpenaei Orland Maintained in Ponds. Jurnal Biosains Pascasarjana, 19.

Sarjito., Apriliani, M., Afriani, D \& Haditomo, A.H.C. 2015. Agensia Penyebab Vibriosis Pada Udang Vaname (Litopenaus gariepinus) yang Dibudidayakan Secara Intensif di Kendal. Jurnal Kelautan Tropis 18, (3): 189-196.

Suciati, A., Wardiyanto, dan Sumino. 2012. Efektivitas Ekstrak Daun Rhizophora muncronata dalam Menghambat Pertumbuhan Aeromonas salmonicida dan Vibrio harveyi. J. Rekayasa dan Teknologi Budidaya Perairan, 1 (1): 2 .

Susanti., Prayitno, S. B \& Sarjito. 2016. Penggunaan Ekstrak Daun Bakau (Rhizopora apiculata) Untuk Pengobatan Kepiting Bakau (Scylla serrata) Yang Diinfeksi Bakteri Vibrio Harveyi Terhadap Kelulushidupan. Jornal of Aquaculture Management and Technology, 5 (2): 18-25. 